\title{
A Theoretical Approach to Determine the Total Resistance on Different Trawl Gears Used in Turkey
}

\author{
Ozan Soykan ${ }^{1}$ (D), Celalettin Aydın ${ }^{1,2}$ (i)
}

Cite this article as: Soykan, O., \& Aydin, C. (2022). A theoretical approach to determine the total resistance on different trawl gears used in Turkey Aquatic Sciences and Engineering, 37(2), 86-99.

\author{
ORCID IDs of the author: \\ O.S. $0000-0002-2227-1245$ \\ C.A. $0000-0001-8993-6013$ \\ ${ }^{1}$ Ege University Faculty of Fisheries, \\ izmir, Turkey \\ ${ }^{2}$ Ege University Urla Maritime Vocational \\ School, Izmir, Turkey \\ Submitted: \\ 22.09.2021 \\ Revision Requested: \\ 04.12.2021 \\ Last Revision Received: \\ 19.01.2022 \\ Accepted: \\ 21.01.2022 \\ Online Published: \\ 00.00 .0000 \\ Correspondence: \\ Ozan Soykan \\ E-mail: \\ ozan.soykan@ege.edu.tr
}

\begin{abstract}
The study aims to theoretically determine the total resistance forces acting on bottom trawls used in the commercial trawl fishery around the Turkish Peninsula. For this purpose, a total of 14 (2 for Black Sea, 2 for Sea of Marmara, 6 for Aegean Sea and 4 Mediterranean Sea) trawl gears were examined during the study representing all types of the bottom trawl fishery (e.g., fish targeted, shrimp targeted and mix) in Turkey. The calculation of the hydrodynamic forces of the gears was based on the determination of each gear component; net, floaters, sweep, door, warp and the friction force caused by footrope, sweep and door. The total resistance of trawl gears was calculated according to different towing speeds and warp lengths. Average resistance values of the examined nets with a $500 \mathrm{~m}$ warp length indicated that the frictional force of the trawl door composed more than $41.3 \%$ of the total resistance, followed by net (39.4\%), both doors (6.3\%), footrope friction (6.1\%), sweep frictions (3.1\%) and the rest belonged to sweeps, warps and floaters (totally $3.8 \%$ ). It was determined that resistance caused by friction including sweeps, footrope and doors constituted more than $50 \%$ of the total resistance. Among the examined gears, the greatest resistance values were determined for the 600 meshes tailored-traditional Mediterranean type trawl gear.
\end{abstract}

Keywords: Bottom trawl, total resistance, friction, hydrodynamic

\section{INTRODUCTION}

Trawls are one of the most important commercial fishing gears and account for almost a quarter of the global landed marine catch (Amoroso et al., 2018; Cashion et al., 2018). The target catch of trawl fishery is both demersal and pelagic species located in the water column. The gears are constituted by a set of the net, warp wire, trawl doors, sweeps, floaters, and sinkers. These elements should work well-matched with each other for good fishing performance. On the other hand, sea trials in order to understand the performance of these complex structures are expensive (Winger, DeLouche, \& Legge, 2006). Therefore, mostly trawl performance studies were investigated by flume tank tests (Ferro, van Marlen, \& Hansen, 1996; Balash,
2012), numerical modelling (Tsukrov, Eroshkin, Fredriksson, Swift, \& Çelikkol B, 2003; Lee, Lee, Cha, Kim, \& Lee, 2005; Priour, 2009; Tang, Dong, $\mathrm{Xu}, \mathrm{Zhao}, \& \mathrm{Bi}, 2017$ ) analytical modelling (Park, 2007), software simulation (Lee et al., 2005; Priour, 2013). Numerical modelling and simulation, in particular, are becoming popular methods of evaluating trawl designs and assessing their performance during the early stages of gear development (Fiorentini, Sala, Hansen, Cosimi, \& Palumbo, 2004).

The Turkish Peninsula is surrounded by different physicochemical and geological features which create particular species diversity and the catch composition of commercial fishery shows variety in each sea (Bilecenoğlu, Kaya, Cihangir, \& Çiçek, 2014). More than 90\% of de- 
mersal fishes are landed by the trawl fishery in Turkey (Soykan, Akgül, \& Kınacıgil, 2016). Trawls have a variety in size and types which are complex in their design, material choice, and construction. There are many scientific studies conducted on trawls, but most of them focused on selectivity (both size and species) (Aydın, Tokaç, Ulaş, Maktay, \& Şensurat, 2011; Özbilgin, Tokaç, \& Kaykaç, 2012; Tokaç, Herrmann, Aydın, Kaykaç, Ünlüler, \& Gökce, 2014), discard characteristics (Soykan et al., 2016; Soykan, Bakır, \& Kınacıgil, 2019), survival ratios (Düzbastılar et al., 2010) and other aspects of the demersal trawl fishery in Turkey (Stewart, 2002). On the other hand, scientific interest in resistance and other hydrodynamic effects is very limited and scarce in Turkey. Only Düzbastılar, Tosunoğlu, \& Kaykaç (2003) calculated the resistance values of conventional and tailored demersal trawl nets. On the other hand, choosing the right size trawl according to the power of the vessel including the other components of the gear such as doors and footrope is crucial for fuel consumption and catch efficiency.

The study aims to be a theoretical approach to determine hydrodynamic effects on different trawl gears used in Turkey's commercial trawl fishery. The present work is the first theoretical study on the hydrodynamic forces on various types of bottom trawls considering the friction force and resistance of floaters for Turkey.

\section{MATERIAL AND METHODS}

\section{Trawl gears}

Resistance forces on trawl nets were well described by Fridman (1973) and Düzbastılar et al. (2003). Due to the lack of gear standardization in the Turkish trawl fishery, almost each trawler has its own trawl net design although there are some restrictions, especially on mesh size at the codend. Bottom trawls investigated for theoretical evaluation here have been used in commercial fishing around Turkey; the Black Sea, Sea of Marmara, Aegean Sea and the Mediterranean Sea. A total of 14 trawl nets (2 for the Black sea, 2 for the Sea of Marmara, 6 for the Aegean Sea and 4 for the Mediterranean Sea) were examined during the study, and those were the representatives of each type of the bottom trawl fishery (e.g., fish targeted, shrimp targeted and mix) in Turkey. The nets emphasized in this study were chosen from published scientific papers around Turkish territorial waters (Table 1).

Total hydrodynamic resistance $\left(R_{T}\right)$ was calculated by adding the resistance of each gear component; net, floaters, sweep, door, warp and the friction force caused by the footrope, sweep and door with the following formulae:

$R_{\mathrm{T}}=R_{\mathrm{N}}+2 R_{\mathrm{D}}+2\left(R_{\mathrm{S}}+R_{\mathrm{W}}\right)+\mathrm{n} R_{\mathrm{F}}+F_{\mathrm{F}}$

$R_{\mathrm{T}}$ : Total resistance $(\mathrm{N})$

$R_{\mathrm{N}}:$ Net resistance $(\mathrm{N})$

$R_{\mathrm{D}}$ : Door resistance $(\mathrm{N})$

$R_{\mathrm{S}}:$ Sweep resistance $(\mathrm{N})$

$R_{\mathrm{w}}:$ Warp resistance $(\mathrm{N})$

n: Number of floaters

$R_{\mathrm{F}}$ : Floater resistance $(\mathrm{N})$

Friction forces consist of friction of the footrope, sweep and doors

$$
\begin{aligned}
& F_{\mathrm{F}}=F_{\mathrm{FF}}+F_{\mathrm{FS}}+F_{\mathrm{FD}} \\
& F_{\mathrm{F}}=\text { Friction forces } \\
& F_{\mathrm{FF}}=\text { Friction by footrope } \\
& F_{\mathrm{FS}}=\text { Friction by sweep } \\
& F_{\mathrm{FD}}=\text { Friction by doors }
\end{aligned}
$$

\begin{tabular}{|c|c|c|c|c|}
\hline Code & Trawls types & $\begin{array}{l}\text { Target spe- } \\
\text { cies }\end{array}$ & Region & Literature \\
\hline BS1 & 800 meshes & Fish & Black Sea & Özdemir et al., 2014 \\
\hline BS2 & 900 meshes tailored & Fish & Black Sea (Samsun) & Kaykaç et al., 2017 \\
\hline SM1 & 500 meshes traditional & Shrimp, fish & Sea of Marmara (Bandırma -Erdek) & Zengin et al., 2004 \\
\hline SM2 & 260 meshes tailored & Shrimp fish & $\begin{array}{l}\text { Sea of Marmara (Tekirdağ-Şarköy, } \\
\text { Hoşköy, Barbaros) }\end{array}$ & Zengin et al., 2004 \\
\hline AS1 & 900 meshes tailored & Fish & Aegean Sea (İzmir) & Tosunoğlu \& Aydın, 2007 \\
\hline AS2 & 1200 meshes tailored & Shrimp, fish & Aegean Sea (İzmir) & Tosunoğlu \& Aydın, 2007 \\
\hline AS3 & 1100 meshes tailored & Shrimp, fish & Aegean Sea (İzmir) & Aydın \& Tosunoğlu, 2009 \\
\hline AS4 & 600 meshes tailored & Fish & Aegean Sea (Foça) & Tokaç et al., 2010 \\
\hline AS5 & 700 meshes traditional & Fish & Aegean Sea (Çanakkale) & Tokaç et al., 2010 \\
\hline AS6 & 600 meshes traditional & Fish & Aegean (Bodrum) & Tokaç et al., 2010 \\
\hline MS1 & 650 meshes traditional & Shrimps, fish & Mediterranean (İskenderun Bay) & Demirci et al., 2008 \\
\hline MS2 & 600 meshes tailored & Shrimp & Mediterranean (Iskenderun Bay) & Demirci et al., 2008 \\
\hline MS3 & 500 meshes tailored-traditional & Fish & Mediterranean (Iskenderun Bay) & Demirci et al., 2008 \\
\hline MS4 & 600 meshes tailored-traditional & Fish, shrimps & Mediterranean (Mersin Bay) & Özbilgin et al., 2018 \\
\hline
\end{tabular}

Table 1. General specifications of trawl nets evaluated in the study. 


\section{Hydrodynamic resistance of trawl net}

Trawl net sections in various sizes are composed of different materials. To estimate the hydrodynamic resistance forces, technical parameters such as rope diameter $\mathrm{d}(\mathrm{mm})$, the mesh length I $(\mathrm{mm})$ and their ratio to each other $(d / l)$ were taken from the technical plans. Metric characteristics of each section of the trawl nets were given in Table 2.

Resistance of the net $\left(R_{n}\right)$ was calculated by the following formulas according to Nomura \& Yamazaki (1975);

$$
R_{n}=25 \times \frac{d}{l} \times \lambda^{2} \times v^{2}
$$

$R_{\mathrm{n}}=$ Resistance of the net

$\frac{d}{l}=$ ratio between the diameter of net line and mesh length $(\mathrm{mm})$

$\lambda=$ Length of the headrope $(\mathrm{m})$

$v=$ Towing speed $\left(\mathrm{ms}^{-1}\right)$

\section{Frictional resistance of footrope}

The length, material and diameter of the footrope differed in each net (Table 3). Footrope weight in water was calculated with the following formulas:

Table 2. Metric characteristics of bottom trawl nets.

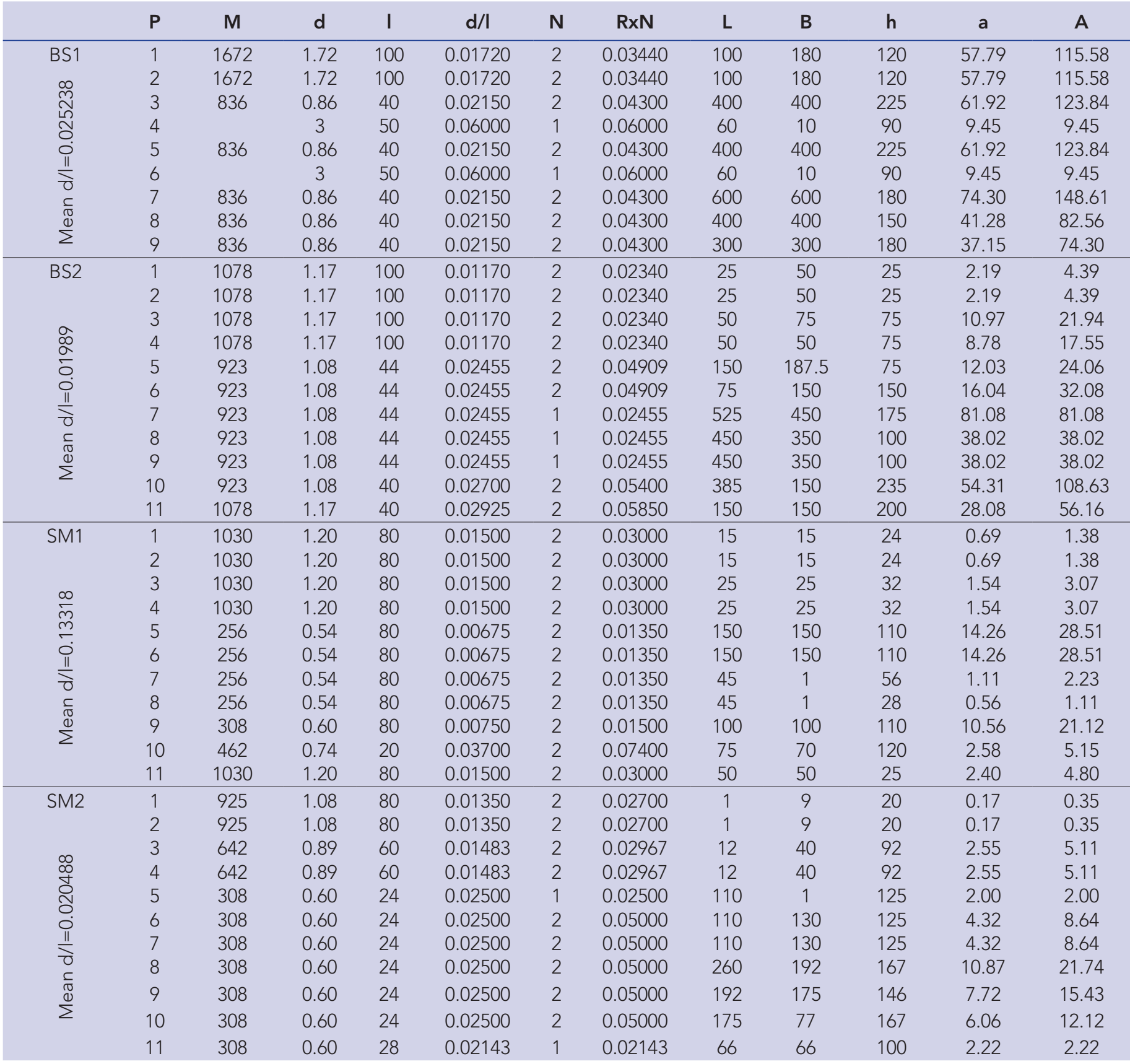


Table 2. Continue.

\begin{tabular}{|c|c|c|c|c|c|c|c|c|c|c|c|c|}
\hline & $P$ & $M$ & d & I & $d / l$ & $\mathbf{N}$ & $\mathrm{RxN}$ & $\mathbf{L}$ & B & $\mathrm{h}$ & a & A \\
\hline AS1 & 1 & 923 & 1.26 & 110 & 0.01145 & 2 & 0.02291 & 5 & 50 & 45 & 3.43 & 6.86 \\
\hline \multirow{12}{*}{ 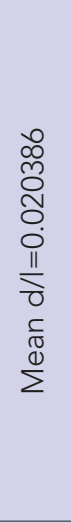 } & 2 & 923 & 1.26 & 110 & 0.01145 & 2 & 0.02291 & 5 & 50 & 45 & 3.43 & 6.86 \\
\hline & 3 & 923 & 1.26 & 110 & 0.01145 & 2 & 0.02291 & 75 & 100 & 75 & 18.19 & 36.38 \\
\hline & 4 & 923 & 1.26 & 110 & 0.01145 & 2 & 0.02291 & 50 & 50 & 75 & 10.40 & 20.79 \\
\hline & 5 & 692 & 1.09 & 46 & 0.02370 & 2 & 0.04739 & 200 & 250 & 32,5 & 7.33 & 14.67 \\
\hline & 6 & 692 & 1.09 & 46 & 0.02370 & 2 & 0.04739 & 100 & 100 & 100 & 10.03 & 20.06 \\
\hline & 7 & 692 & 1.09 & 46 & 0.02370 & 2 & 0.04739 & 285 & 200 & 167,5 & 40.73 & 81.46 \\
\hline & 8 & 692 & 1.09 & 46 & 0.02370 & 2 & 0.04739 & 100 & 150 & 32,5 & 4.07 & 8.15 \\
\hline & 9 & 692 & 1.09 & 46 & 0.02370 & 2 & 0.04739 & 185 & 150 & 67,5 & 11.34 & 22.68 \\
\hline & 10 & 692 & 1.09 & 46 & 0.02370 & 2 & 0.04739 & 350 & 250 & 100 & 30.08 & 60.17 \\
\hline & 11 & 692 & 1.09 & 46 & 0.02370 & 2 & 0.04739 & 250 & 150 & 100 & 20.06 & 40.11 \\
\hline & 12 & 692 & 1.09 & 46 & 0.02370 & 2 & 0.04739 & 150 & 150 & 100 & 15.04 & 30.08 \\
\hline & 13 & & 3.50 & 90 & 0.03889 & 1 & 0.03889 & 70 & 70 & 50 & 22.05 & 22.05 \\
\hline \multirow[t]{3}{*}{ AS2 } & 1 & 923 & 1.26 & 110 & 0.01145 & 2 & 0.02291 & 5 & 50 & 45 & 3.43 & 6.86 \\
\hline & 2 & 923 & 1.26 & 110 & 0.01145 & 2 & 0.02291 & 5 & 50 & 45 & 3.43 & 6.86 \\
\hline & 3 & 923 & 1.26 & 110 & 0.01145 & 2 & 0.02291 & 66,5 & 100 & 100 & 2308 & 46.15 \\
\hline \multirow{8}{*}{ 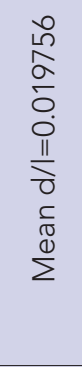 } & 4 & 923 & 1.26 & 110 & 0.01145 & 2 & 0.02291 & 50 & 50 & 100 & 13.86 & 27.72 \\
\hline & 5 & 692 & 1.09 & 46 & 0.02370 & 2 & 0.04739 & 200 & 250 & 100 & 22.56 & 45.13 \\
\hline & 6 & 692 & 1.09 & 46 & 0.02370 & 2 & 0.04739 & 350 & 300 & 100 & 32.59 & 65.18 \\
\hline & 7 & 692 & 1.09 & 46 & 0.02370 & 2 & 0.04739 & 100 & 200 & 200 & 30.08 & 60.17 \\
\hline & 8 & 692 & 1.09 & 46 & 0.02370 & 2 & 0.04739 & 600 & 400 & 200 & 100.28 & 200.56 \\
\hline & 9 & 692 & 1.09 & 46 & 0.02370 & 2 & 0.04739 & 400 & 200 & 200 & 60.17 & 120.34 \\
\hline & 10 & 692 & 1.09 & 46 & 0.02370 & 2 & 0.04739 & 200 & 200 & 200 & 40.11 & 80.22 \\
\hline & 11 & & 3.50 & 90 & 0.03889 & 1 & 0.03889 & 70 & 70 & 100 & 44.10 & 44.10 \\
\hline \multirow[t]{2}{*}{ AS3 } & 1 & 692 & 1.09 & 95 & 0.01147 & 2 & 0.02295 & 5 & 50 & 45 & 2.56 & 5.13 \\
\hline & 2 & 692 & 1.09 & 95 & 0.01147 & 2 & 0.02295 & 5 & 50 & 45 & 2.56 & 5.13 \\
\hline \multirow{8}{*}{ 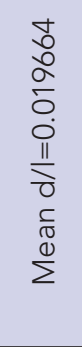 } & 3 & 692 & 1.09 & 95 & 0.01147 & 2 & 0.02295 & 66,5 & 100 & 100 & 17.24 & 34.48 \\
\hline & 4 & 692 & 1.09 & 95 & 0.01147 & 2 & 0.02295 & 50 & 50 & 100 & 10.36 & 20.71 \\
\hline & 5 & 615 & 1.02 & 44 & 0.02318 & 2 & 0.04636 & 200 & 225 & 75 & 14.31 & 28.61 \\
\hline & 6 & 615 & 1.02 & 44 & 0.02318 & 2 & 0.04636 & 325 & 275 & 100 & 26.93 & 53.86 \\
\hline & 7 & 615 & 1.02 & 44 & 0.02318 & 2 & 0.04636 & 100 & 175 & 175 & 21.60 & 43.20 \\
\hline & 8 & 615 & 1.02 & 44 & 0.02318 & 2 & 0.04636 & 550 & 150 & 400 & 125.66 & 251.33 \\
\hline & 9 & 615 & 1.02 & 44 & 0.02318 & 2 & 0.04636 & 150 & 150 & 200 & 26.93 & 53.86 \\
\hline & 10 & & 5.00 & 100 & 0.05000 & 1 & 0.05000 & 70 & 70 & 75 & 52.50 & 52.50 \\
\hline \multirow[t]{5}{*}{ AS4 } & 1 & & 3,00 & 110 & 0.02727 & 2 & 0.05455 & 50 & 100 & 50 & 24.75 & 49.50 \\
\hline & 2 & & 3.00 & 64 & 0.04688 & 2 & 0.09375 & 1 & 50 & 50 & 4.90 & 9.79 \\
\hline & 3 & & 3.00 & 64 & 0.04688 & 2 & 0.09375 & 100 & 150 & 50 & 24.00 & 48.00 \\
\hline & 4 & & 3.00 & 56 & 0.05357 & 1 & 0.05357 & 250 & 200 & 100 & 75.60 & 75.60 \\
\hline & 5 & & 3.00 & 28 & 0.10714 & 1 & 0.10714 & 200 & 1 & 200 & 33.77 & 33.77 \\
\hline \multirow{10}{*}{$\begin{array}{l}0 \\
0 \\
10 \\
0 \\
0 \\
11 \\
\frac{1}{2} \\
\frac{1}{0} \\
0 \\
0\end{array}$} & 6 & & 3.00 & 56 & 0.05357 & 2 & 0.10714 & 100 & 100 & 100 & 33.60 & 67.20 \\
\hline & 7 & & 3.00 & 28 & 0.10714 & 2 & 0.21429 & 100 & 100 & 200 & 33.60 & 67.20 \\
\hline & 8 & & 3.00 & 44 & 0.06818 & 2 & 0.13636 & 100 & 100 & 150 & 39.60 & 79.20 \\
\hline & 9 & & 3.00 & 64 & 0.04688 & 1 & 0.04688 & 10 & 50 & 80 & 9.22 & 9.22 \\
\hline & 10 & & 3.00 & 64 & 0.04688 & 1 & 0.04688 & 10 & 50 & 80 & 9.22 & 9.22 \\
\hline & 11 & & 3.00 & 64 & 0.04688 & 1 & 0.04688 & 50 & 60 & 7 & 1.48 & 1.48 \\
\hline & 12 & & 3.00 & 64 & 0.04688 & 1 & 0,04688 & 50 & 60 & 7 & 1.48 & 1.48 \\
\hline & 13 & & 3.00 & 56 & 0.05357 & 1 & 0,05357 & 200 & 100 & 100 & 50.40 & 50.40 \\
\hline & 14 & & 3.00 & 48 & 0.06250 & 1 & 0,06250 & 100 & 1 & 100 & 14.54 & 14.54 \\
\hline & 15 & & 3,00 & 88 & 0.03409 & 1 & 0,03409 & 50 & 50 & 30 & 7.92 & 7.92 \\
\hline
\end{tabular}


Table 2. Continue.

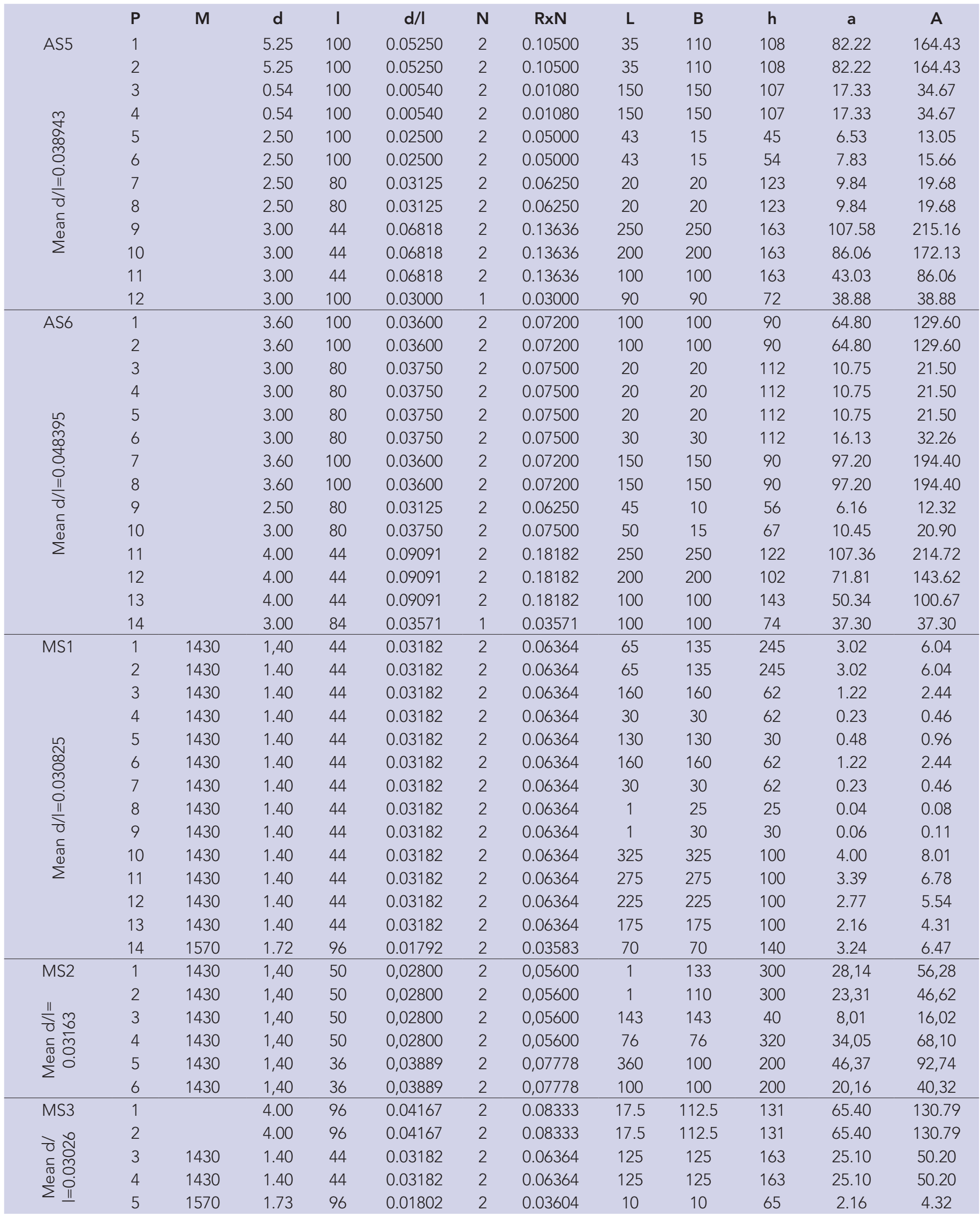




\begin{tabular}{|c|c|c|c|c|c|c|c|c|c|c|c|c|}
\hline \multirow{2}{*}{ Table 2.} & \multicolumn{12}{|c|}{ Continue. } \\
\hline & $\mathbf{P}$ & $M$ & $d$ & I & $d / l$ & $\mathbf{N}$ & $\mathrm{RxN}$ & L & B & $\mathrm{h}$ & a & A \\
\hline \multirow{7}{*}{ 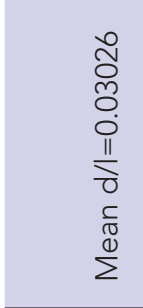 } & 6 & 1570 & 1.73 & 96 & 0.01802 & 2 & 0.03604 & 10 & 10 & 65 & 2.16 & 4.32 \\
\hline & 7 & & 4.00 & 96 & 0.04167 & 2 & 0.08333 & 35 & 15 & 47 & 9.02 & 18.05 \\
\hline & 8 & 1570 & 1.73 & 96 & 0.01802 & 2 & 0.03604 & 10 & 10 & 38 & 1.26 & 2.52 \\
\hline & 9 & 1430 & 1.40 & 44 & 0.03182 & 2 & 0.06364 & 250 & 250 & 61 & 18.79 & 37.58 \\
\hline & 10 & 1430 & 1.40 & 44 & 0.03182 & 2 & 0.06364 & 200 & 200 & 41 & 10.10 & 20.20 \\
\hline & 11 & 1430 & 1.40 & 44 & 0.03182 & 2 & 0.06364 & 150 & 150 & 245 & 45.28 & 90.55 \\
\hline & 12 & 1570 & 1.73 & 88 & 0.01966 & 1 & 0.01966 & 70 & 70 & 120 & 25.58 & 25.58 \\
\hline \multirow[t]{4}{*}{ MS4 } & 1 & 1280 & 1.30 & 100 & 0.01300 & 2 & 0.02600 & 68 & 68 & 54.5 & 9.64 & 19.27 \\
\hline & 2 & 1280 & 7.50 & 44 & 0.17045 & 2 & 0.34091 & 5 & 50 & 63.6 & 11.54 & 23.09 \\
\hline & 3 & 1280 & 7.50 & 44 & 0.17045 & 2 & 0.34091 & 125 & 125 & 163 & 134.48 & 268.95 \\
\hline & 4 & 1280 & 7.50 & 44 & 0.17045 & 2 & 0.34091 & 50 & 5 & 129.5 & 23.50 & 47.01 \\
\hline \multirow{8}{*}{ 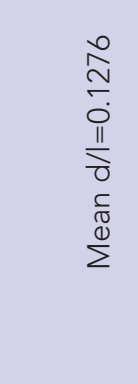 } & 5 & 1280 & 7.50 & 44 & 0.17045 & 1 & 0.17045 & 100 & 5 & 129.5 & 44.87 & 44.87 \\
\hline & 6 & 1280 & 1.30 & 100 & 0.01300 & 2 & 0.02600 & 68 & 68 & 54.5 & 9.64 & 19.27 \\
\hline & 7 & 1280 & 7.50 & 44 & 0.17045 & 2 & 0.34091 & 100 & 100 & 63.6 & 41.98 & 83.95 \\
\hline & 8 & 1280 & 7.50 & 44 & 0.17045 & 2 & 0.34091 & 5 & 50 & 63.6 & 11.54 & 23.09 \\
\hline & 9 & 1280 & 7.50 & 44 & 0.17045 & 2 & 0.34091 & 100 & 100 & 180 & 118.80 & 237.60 \\
\hline & 10 & 1280 & 7.50 & 44 & 0.17045 & 1 & 0.17045 & 200 & 10 & 180 & 124.74 & 124.74 \\
\hline & 11 & 1280 & 3.50 & 44 & 0.07955 & 1 & 0.07955 & 300 & 300 & 94 & 86.86 & 86.86 \\
\hline & 12 & 1280 & 3.00 & 88 & 0.03409 & 1 & 0.03409 & 60 & 60 & 68.1 & 21.57 & 21.57 \\
\hline
\end{tabular}

(S: Sections, M: Material T: Rtex values (twine thickness), d: Diameter ( $\mathrm{mm}$ ) of twine, I: Mesh size (mm), N: Number of each section, L: Number of meshes on the upper edge, B: Number of meshes on the lower edge, h: Number of longitudinal meshes, a: Twine surface area of each section $\left(\mathrm{m}^{2}\right)$, A: Total twine surface area $\left(\mathrm{m}^{2}\right) \mathrm{PA}$ :

Polyamide, PE: Polyethylene, PP: Polypropylene

$$
\begin{aligned}
& F_{B}=\times g \times V \\
& F=m \times g \\
& F_{\text {Net }}=F-F_{B}
\end{aligned}
$$

Where;

$$
\begin{aligned}
& \mathrm{F}_{\mathrm{B}}=\text { Buoyant force }(\mathrm{N}) \\
& \rho=\text { Density of sea water, } 1.026\left(\mathrm{kgm}^{-3}\right) \\
& \mathrm{g}=\text { acceleration of gravity }\left(\mathrm{ms}^{-2}\right) \\
& \mathrm{V}=\text { Volume of body submerged in fluid }\left(\mathrm{m}^{3}\right)
\end{aligned}
$$

In order to increase the impact of ground contact, additional weights have been applied on the footrope. Kaykaç, Zengin, Özcan-Akpınar, \& Tosunoğlu (2014) stated the additional weight for Black Sea trawlers to be $100-150 \mathrm{~kg}$. Considering this, a mean value of $1226.3 \mathrm{~N}(125 \mathrm{~kg})$ additional weight was taken for Black Sea and Sea of Marmara. Özbilgin et al. (2018), reported that the average value of the additional weights on the footrope used in the Mediterranean as $1304.3 \mathrm{~N}(133 \mathrm{~kg})$. Thus, we accepted this value in calculations for the Mediterranean. Due to lack of literature regarding additional weight on the footrope for the Aegean Sea, a total of $1471.5 \mathrm{~N}(150 \mathrm{~kg})$ additional weight was accounted (personal communication with Aydın Kuruca, a net manufacturer and skipper). Total weight of footropes was calculated by adding the weights of footrope itself and the additional weight taking the floatation force of the material into account.

\begin{tabular}{|c|c|c|c|c|c|}
\hline$\stackrel{ \pm}{z}$ & $\begin{array}{l}\frac{\pi}{\frac{\pi}{2}} \\
\frac{\pi}{\pi} \\
\sum\end{array}$ & 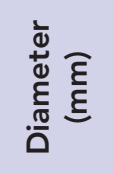 & 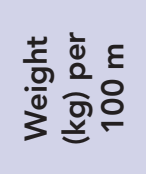 & 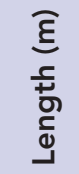 & 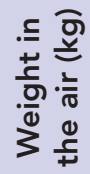 \\
\hline BS1 & PP & 28 & 35.4 & 33.2 & 11.8 \\
\hline BS2 & PP & 32 & 46.3 & 35.4 & 16.4 \\
\hline SM1 & PP & 28 & 35.4 & 22.0 & 7.8 \\
\hline SM2 & PP & 28 & 35.4 & 18.6 & 6.6 \\
\hline AS1 & PP & 20 & 18.1 & 38.5 & 7.0 \\
\hline AS2 & $P P+P P$ & $20+10$ & $18.1+4.5$ & 52.2 & 11.7 \\
\hline AS3 & $P P+P P$ & $20+10$ & $18.1+4.5$ & 45.0 & 10.1 \\
\hline AS4 & PA & 30 & 55.5 & 29.6 & 16.4 \\
\hline AS5 & COMB & 18 & 48.8 & 32.0 & 15.6 \\
\hline AS6 & COMB & 36 & 60.3 & 28.5 & 17.2 \\
\hline MS1 & PP & 32 & 46.3 & 35.1 & 16.3 \\
\hline MS2 & PP & 28 & 48.4 & 35.8 & 17.3 \\
\hline MS3 & PA & 32 & 63.2 & 39.7 & 25.0 \\
\hline MS4 & PA & 28 & 106 & 20.3 & 21.5 \\
\hline
\end{tabular}

\section{Hydrodynamic resistance of floaters}

Floaters used in trawls are made of plastic materials, spherical shape ranging in different thickness values according to depth
Table 3. Parameters for calculating the total weight of footrope with respect to specifications of each net.

and pressure. The hydrodynamic resistance of floaters $\left(R_{\mathrm{F}}\right)$ was calculated by using Newton's model;

$$
R_{\mathrm{F}}=\frac{C_{D f}}{2} \times \rho \times v^{2} \times S_{\mathrm{f}}
$$


Where $C_{D f}$ is the drag coefficient for a sphere, with a value of 0.47 (Fridman, 1969), = density of sea water $\left(1.026 \mathrm{~g} / \mathrm{cm}^{-3}\right)$. Calculation of the floater's surface area $\left(S_{f}\right)$ was considered as the sphere's projected area, the diametral circle (Pereira, 2012). Number of floaters during a trawl operation differs according to area and the target species. Mostly, a diameter of $20 \mathrm{~cm}$ spherical floaters were used around the Turkish Peninsula. While the number of those were taken to be 6 for the Black Sea and the Sea of Marmara, 10 for the Aegean Sea and the Mediterranean, based on the literature survey and the interviews with the skippers in each region (personal communication with Mustafa Kuraca and İsmail Öksüz who are the owner and the skipper of trawlers).

\section{Resistance of sweep, door and warp}

Auxiliary equipment such as sweep, doors and warp were kept constant in order to calculate hydrodynamic effects. Those were determined for different depths and towing speeds. Sweep was made of combined material (Polypropylene and lead) with a diameter of $32 \mathrm{~mm}$, and it was assumed to be 200 $\mathrm{m}$ long in each gear. Weight per meter of the sweep was $8.83 \mathrm{~N}$ $(0.9 \mathrm{~kg})$ (personal communication with the rope manufacturer). Trawl doors (otter boards), evaluated in the study, have a rectangular shape, wooden material, surrounded by an iron frame, a surface area of 1,71 $\mathrm{m}^{2}$ and a weight of $1.57 \mathrm{kN}(160 \mathrm{~kg})$, and the warp was made of steel wire with a diameter of $10 \mathrm{~mm}$. Resistances of the sweep, $\left(R_{s}\right)$, the warp $\left(R_{w}\right)$ and door $\left(R_{d}\right)$ were calculated by the following formulas according to Nomura \& Yamazaki (1975);

$$
\begin{aligned}
& R_{\mathrm{S}=} C_{\mathrm{Ds}} / 2 \times \rho \times d_{\mathrm{s}} \times L_{\mathrm{s}} \times v^{2} \\
& R_{\mathrm{S}}=\text { Resistance of sweep } \\
& C_{\mathrm{Ds}}=\text { Resistance coefficient of sweep } \\
& \rho=\text { Density of seawater }\left(1.026 \mathrm{~g} / \mathrm{cm}^{-3}\right) \\
& d_{\mathrm{s}}=\text { Diameter of sweep } \\
& L_{\mathrm{s}}=\text { Length of the sweep } \\
& R_{\mathrm{W}}=C_{\text {Dw }} / 2 \times \rho \times d_{\mathrm{w}} \times L_{\mathrm{w}} \times v^{2} \\
& R_{\mathrm{w}}=\text { Resistance of warp, } \\
& C_{\mathrm{Dw}}=\text { Resistance coefficient of } \mathrm{warp} \\
& \rho=\text { Density of seawater }\left(1.026 \mathrm{~g} / \mathrm{cm}^{-3}\right) \\
& d_{\mathrm{w}}=\text { Diameter of warp } \\
& L_{\mathrm{w}}=\text { Length of the warp } \\
& R_{D}=\frac{C_{D d}}{2} \times \rho \times v^{2} \times S_{\mathrm{d}} \\
& R_{\mathrm{D}}=\text { Resistance of the door } \\
& C_{D d}=\text { Estimated drag coefficient of trawl door (hydrodynamic } \\
& S_{\mathrm{d}}=\text { Surface area of the door }\left(\mathrm{m}^{2}\right)
\end{aligned}
$$

\section{Friction force}

Friction force that acts in the opposite direction of the tow (between structural elements of trawl gear such as door, sweep and footrope and sea floor) were also calculated. The sliding friction depends on the weight of the equipment in water and the seabed conditions (Sala, 2013). The footrope weight is considered as the overall weight (including the additional weights) depending on the material of the footrope in each net (Sala, 2013). Polypropylene material which has a lower density than sea water tends to float, the footrope, therefore, its weight in the water was subtracted during the calculation of overall weight. The weight of footropes made of other materials is assumed as the overall weight used to sink the line as recommended by Sala (2013). The effective otter board weight is the weight in water. The difference between the doors' weight in water and air is related to the used material (Sala, 2013). The weight of the otter board in water is usually around $87 \%$ of the weight in the air when the otter board is constructed with solid steel, while it is $60 \%$ when wood is preferred (Sala, 2013). Expression of the friction force is given by the following equation (Sala, 2013):

$$
\mathrm{F}_{f r}=\mathrm{k} \cdot \mathrm{N}
$$

Where $F_{\mathrm{fr}}$ is the friction force, $\mathrm{k}$ is the friction coefficient on the element and the contact surface and $\mathrm{N}$ is the reaction on the contact surface. Although there are different values for the friction coefficient according to the sediment type (Fridman, 1969; Sala, 2013), ground effect coefficients were taken as 0.61, 0.80 and 1.20, for door, footrope and sweep, respectively (Sala, 2013).

\section{RESULTS AND DISCUSSION}

The hydrodynamic resistance of 14 different trawl gears used around Turkey was determined theoretically. Net, floater, sweep, door, warp resistances and friction forces (occurred by footrope, sweeps and doors) of each gear was separately calculated according to different depths and towing speeds.

\section{Hydrodynamic resistance of the nets}

Among the investigated nets, the greatest total twine surface area belonged to the AS6 with a value of $1136.3 \mathrm{~m}^{2}$ and the smallest to MS1 with $50.1 \mathrm{~m}^{2}$ (Figure 1).

Hydrodynamic resistance force of the trawl nets varied from 1.7 kN (SM2) to $12 \mathrm{kN}$ (MS4) (Table 4). The resistance of the nets be-

\section{Twine surface area $\left(\mathrm{m}^{2}\right)$}

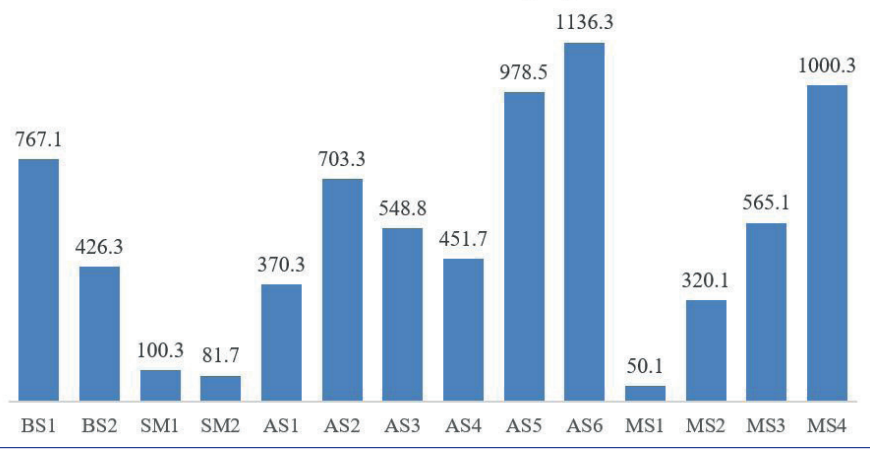

Figure 1. Total twine surface area of examined nets. 
came bigger by the increasing the towing speed and the maximum value was determined to be $39.1 \mathrm{kN}$ (MS4) (Figure 2).

Table 4. Calculating the resistance force of trawl nets depending on Nomura and Yamazaki (1975).

\begin{tabular}{lccccc}
$\begin{array}{l}\text { Net } \\
\text { type }\end{array}$ & $\mathbf{d} / \mathbf{l}$ & $\begin{array}{c}\lambda \\
(\mathbf{m})\end{array}$ & $\lambda^{\mathbf{2}}\left(\mathbf{m}^{\mathbf{2}}\right)$ & $\mathbf{R n}(\mathbf{k g})$ & $\mathbf{R n}(\mathbf{N})$ \\
\hline BS1 & 0.025238 & 28.4 & 806.56 & 508.899 & 4992.3 \\
BS2 & 0.01989 & 29.9 & 894.01 & 444.5465 & 4361.0 \\
SM1 & 0.13318 & 16 & 256 & 852.352 & 8361.5 \\
SM2 & 0.020488 & 18.6 & 345.96 & 177.2007 & 1738.3 \\
AS1 & 0.020386 & 29.5 & 870.25 & 443.5229 & 4350.9 \\
AS2 & 0.019756 & 43.2 & 1866.24 & 921.7359 & 9042.2 \\
AS3 & 0.019664 & 36.5 & 1332.25 & 654.9341 & 6424.9 \\
AS4 & 0.05706 & 18.6 & 345.96 & 493.5119 & 4841.3 \\
AS5 & 0.038943 & 27.2 & 739.84 & 720.2897 & 7066.0 \\
AS6 & 0.048395 & 22.98 & 528.0804 & 638.9113 & 6267.7 \\
MS1 & 0.030825 & 32 & 1024 & 789.12 & 7741.2 \\
MS2 & 0.03163 & 31.8 & 1011.24 & 799.638 & 7844.4 \\
MS3 & 0.03026 & 32.1 & 1030.41 & 779.5052 & 7646.9 \\
MS4 & 0.1276 & 19.64 & 385.7296 & 1230.477 & 12070.9 \\
R: Resistance of the net, d/l: the ratio between the diameter of net line and \\
mesh length (mm), $\lambda$ : Length of the headrope (m), v: Towing speed (ms').
\end{tabular}

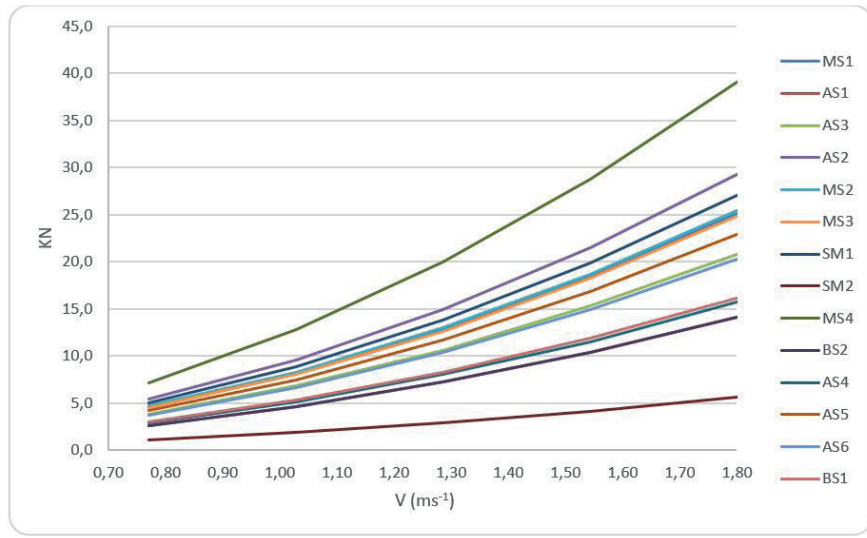

Figure 2. Resistance force of examined trawl nets according to different towing speeds.

\section{Hydrodynamic resistance of Floaters}

The resistance force of a $20 \mathrm{~cm}$ diameter spherical plastic floater ranged between 4.53 and $24.64 \mathrm{~N}$ under different towing speeds (Figure 3). The flotation resistance force for the Black Sea (BS1 and BS2) and the Sea of Marmara (SM1 and SM2) was $147.84 \mathrm{~N}$ for the Aegean (AS1-AS2-AS3-AS4-AS5 and AS6) and the Mediterranean Sea (MS1-MS2-MS3-MS4) was 264.4 N (Table 5).

\section{Hydrodynamic resistance of sweeps}

The resistance coefficient of the sweep was 0.04 at a constant flow angle of $10^{\circ}$ (Düzbastılar et al.; 2003). The diameter and the length of the sweep are $0.032 \mathrm{~m}$ and $200 \mathrm{~m}$, respectively, and these values were taken to be standard measures for all of the examined nets. The resistance value of one sweep varied between $78.5 \mathrm{~N}$ and $427.5 \mathrm{~N}$ at different speeds (Figure 3).

\section{Hydrodynamic resistance of trawl doors}

Doors are basic elements for trawl operations, generating the horizontal opening in the net mouth through the arrangement of the corresponding warps. The resistance force of doors primarily depends on surface area and the towing speed. Hydrodynamic resistance of the trawl door varied in a wide range from $314 \mathrm{~N}$ to $1713 \mathrm{~N}$ (Figure 3). It is worth noting that a 2.3 times increase in the vessel speed resulted in a 5.5 times increase in the hydrodynamic resistance force.

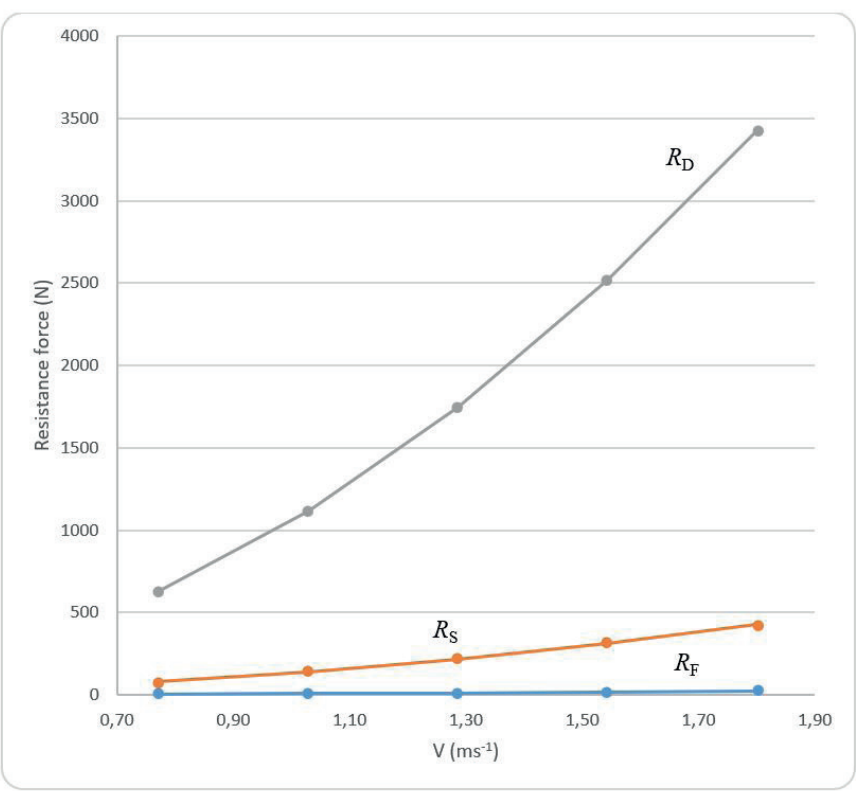

Figure 3. Resistance force of a $20 \mathrm{~cm}$ diameter (D) spherical floater, $200 \mathrm{~m}$ long sweep and trawl doors according to different speeds $\left(R_{\mathrm{F}}\right.$; Resistance of floater, $R_{\mathrm{S}}$ i Resistance of sweep, $R_{D^{\prime}}$ Resistance of door.

\section{Hydrodynamic resistance of warps}

It is necessary that the angle between the warp and water surface should be definite to calculate warp resistance. The angle between the warp and the water surface ranged from $11^{\circ}$ to $24^{\circ}$ and the resistance coefficient of one of the warp is 0.1 at an angle of $20^{\circ}$ (Düzbastılar et al., 2003). The resistance force of a $1 \mathrm{~m}$ steel cable, therefore, ranged from $0.3 \mathrm{~N}$ to $1.7 \mathrm{~N}$ at different speeds (Figure 4). The length of the warps differed according to the depth of the trawl operation. The attitude of Turkish fishermen, in general, is to apply the length of warp between 3 and 5 times the operating depth. Therefore, resistance forces of a warp with different measures were shown in Figure 3 and varied between $766 \mathrm{~N}$ and $4174 \mathrm{~N}$ with different towing speeds.

\section{Frictional resistance}

In general, footrope, sweeps and doors are in contact with the sea bottom which creates frictional resistance. The frictional resistance of these elements was calculated separately. 
Table 5. Cumulative hydrodynamic resistance forces of the floaters according to net type and towing speed.

\begin{tabular}{|c|c|c|c|c|c|c|c|}
\hline \multirow[t]{2}{*}{ Net type } & \multirow[t]{2}{*}{ Area } & \multirow[t]{2}{*}{ \# } & \multicolumn{5}{|c|}{ Towing speed $\left(\mathrm{ms}^{-1}\right)$} \\
\hline & & & 0.77 & 1.03 & 1.29 & 1.54 & 1.80 \\
\hline & & & \multicolumn{5}{|c|}{$\operatorname{Rf}(N)$} \\
\hline SM1-SM2 & $\begin{array}{l}\text { Sea of } \\
\text { Marmara }\end{array}$ & 6 & 27.18 & 48.3 & 75.42 & 108.6 & 147.84 \\
\hline $\begin{array}{l}\text { AS1-AS2-AS3-AS4- } \\
\text { AS5-AS6 }\end{array}$ & Aegean Sea & 10 & 45.3 & 80.5 & 125.7 & 181.0 & 246.4 \\
\hline MS1-MS2-MS3-MS4 & $\begin{array}{l}\text { Mediterra- } \\
\text { nean Sea }\end{array}$ & 10 & 45.3 & 80.5 & 125.7 & 181.0 & 246.4 \\
\hline
\end{tabular}

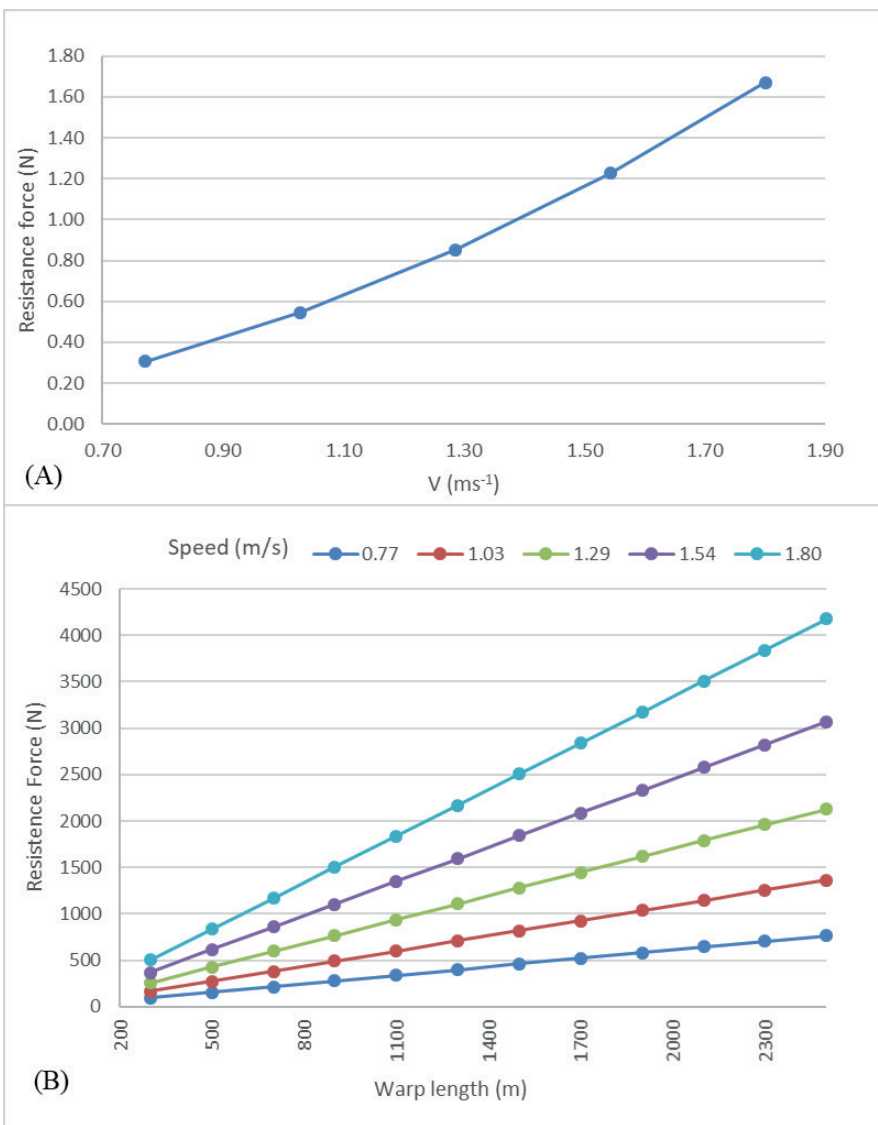

Figure 4. Resistance force of a $1 \mathrm{~m}$ long warp according to different speeds $(A)$ and Resistance force $(N)$ of one of the warps according to different speed and warp length (B).

\section{Footrope friction}

In order to determine footrope friction, the total weight of the footrope (additional weight and footrope weight together) in water was calculated. Estimated friction force caused by the footrope ranged between $835.5 \mathrm{~N}$ (BS2) and 1063.9 N (AS6) (Table 6).

\section{Sweep friction}

The weight of the sweep in water was calculated to be $545.4 \mathrm{~N}$ $(55.6 \mathrm{~kg})$. The friction coefficient between sweep and sand was assumed to be 0.80 (Sala, 2013). Therefore; friction force caused by the sweep was determined as $436.3 \mathrm{~N}$ resulting in $872.6 \mathrm{~N}$ of total friction.

\section{Doors friction}

A wooden material trawl door weighed $1569.6 \mathrm{~N}(160 \mathrm{~kg})$ in the air corresponding to $941.8 \mathrm{~N}(96 \mathrm{~kg})$ weight in the water. Ninety-six $\mathrm{kg}$ weight equals $941.7 \mathrm{~N}$ which is also the normal force $(\mathrm{N})$. The friction coefficient was assumed to be 0.61 , therefore friction force between one door and the sediment was calculated as $5744.3 \mathrm{~N}$. Total amount of friction force created by both doors was determined to be $11488.6 \mathrm{~N}$.

Consequently, the total amount of friction created by sweeps and doors which were kept constant for all type nets was estimated to be $12361.2 \mathrm{~N}$

\section{Total resistance of the examined trawl gears}

The total resistance force of 14 trawl nets was calculated for different towing speeds according to $1 \mathrm{~m}$ long warp lengths. The greatest total resistance for $1 \mathrm{~m}$ warp length belonged to N9, while the lowest value was detected for N8 (Table 7).

Warp length/depth ratio is generally preferred between 3:1 and $5: 1$ by Turkish skippers. If we assume a number of bottom trawl operations at depths of 150-250-400-500 meters, they correspond to a warp length of more or less 500, 1100, 1700 and 2500 m, respectively. Based on this assumption, theoretical total resistance force values varied between 15.4 and $63.1 \mathrm{kN}$ (Figure 5).

In this study, we have determined the hydrodynamic effects on different trawl gears used in Turkish territorial waters based on theoretical assumptions. Each section of a trawl net has different contributions on the total resistance. Average resistance values of the examined nets with $500 \mathrm{~m}$ warp length showed that door frictions composed more than $41.3 \%$ of the total resistance, followed by net (39.4\%), doors (6.3\%), footrope friction (6.1\%), sweep frictions (3.1\%) and the rest belonged to sweeps, warps and floaters (totally 3.8\%). It was determined that resistance caused by friction including sweeps, footrope and doors constituted more than $50 \%$ of the total resistance. Among the examined nets, the greatest resistance values were determined for MS4. While a total of $37.7 \mathrm{kN}$ resistance value was determined for MS4 under a towing speed of 2.5 knots and $500 \mathrm{~m}$ warp 
Table 6. Total weight of footrope in seawater.

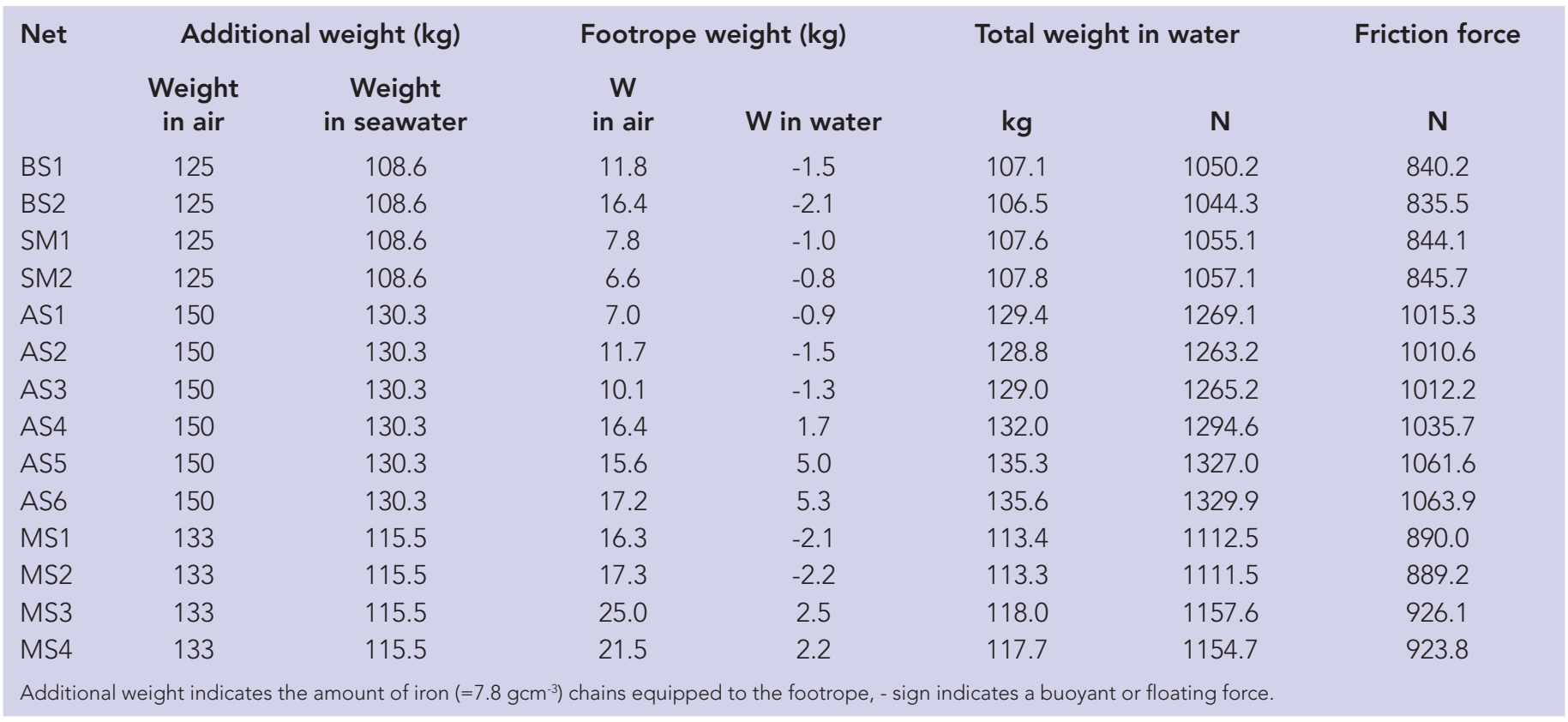

Table 7. Total resistance force of examined trawl gears based on $1 \mathrm{~m}$ long warp length.

\begin{tabular}{|c|c|c|c|c|c|c|c|c|c|c|c|c|c|}
\hline & \multicolumn{2}{|c|}{ Net } & \multirow{2}{*}{$\begin{array}{l}\text { Door } \\
2 R_{D} \\
\end{array}$} & \multirow{2}{*}{$\begin{array}{c}\text { Sweep } \\
2 R_{\mathrm{S}}\end{array}$} & \multirow{2}{*}{$\begin{array}{l}\text { Warp } \\
2 R_{w}\end{array}$} & \multicolumn{3}{|c|}{$\begin{array}{l}\text { Resistance of } \\
\text { floaters }\end{array}$} & \multicolumn{5}{|c|}{ Friction } \\
\hline & v & $R_{N}$ & & & & $R_{F}$ & $n$ & $R_{F T}$ & $F_{F F}$ & $F_{s}$ & $F_{D}$ & $F_{T}$ & $R_{T}$ \\
\hline \multirow{5}{*}{ BS1 } & 0.77 & 2972.8 & 629.3 & 157 & 0.61 & 4.53 & & 27.2 & 840.2 & 872.6 & 11488.6 & 13201.4 & 16988.3 \\
\hline & 1.03 & 5284.9 & 1118.8 & 279.1 & 1.09 & 8.05 & & 48.3 & 840.2 & 872.6 & 11488.6 & 13201.4 & 19933.6 \\
\hline & 1.29 & 8257.7 & 1748.1 & 436.2 & 1.7 & 12.57 & 6 & 75.4 & 840.2 & 872.6 & 11488.6 & 13201.4 & 23720.5 \\
\hline & 1.54 & 11891 & 2517.2 & 628.1 & 2.45 & 18.1 & & 108.6 & 840.2 & 872.6 & 11488.6 & 13201.4 & 28348.8 \\
\hline & 1.8 & 16185 & 3426.2 & 854.9 & 3.34 & 24.64 & & 147.8 & 840.2 & 872.6 & 11488.6 & 13201.4 & 33818.7 \\
\hline \multirow{5}{*}{ BS2 } & 0.77 & 2596.8 & 629.3 & 157 & 0.61 & 4.53 & & 27.2 & 835.5 & 872.6 & 11488.6 & 13196.7 & 16607.6 \\
\hline & 1.03 & 4616.6 & 1118.8 & 279.1 & 1.09 & 8.05 & & 48.3 & 835.5 & 872.6 & 11488.6 & 13196.7 & 19260.6 \\
\hline & 1.29 & 7213.5 & 1748.1 & 436.2 & 1.7 & 12.57 & 6 & 75.4 & 835.5 & 872.6 & 11488.6 & 13196.7 & 22671.6 \\
\hline & 1.54 & 10387.4 & 2517.2 & & 2.45 & 18.1 & & 108.6 & 835.5 & 872.6 & 11488.6 & 96.7 & 26840.5 \\
\hline & 1.8 & 14138.4 & 3426.2 & 854.9 & 3.34 & 24.64 & & 147.8 & 835.5 & 872.6 & 11488.6 & 13196.7 & 31767.4 \\
\hline \multirow{5}{*}{ SM1 } & 0.77 & 4979.1 & 629.3 & 157 & 0.61 & 4.53 & & 27.2 & 844.1 & 872.6 & 11488.6 & 13205.3 & 18998.5 \\
\hline & 1.03 & 8851.7 & 1118.8 & 279.1 & 1.09 & 8.05 & & 48.3 & 844.1 & 872.6 & 11488.6 & 13205.3 & 23504.3 \\
\hline & 1.29 & 13830.7 & 1748.1 & 436.2 & 1.7 & 12.57 & 6 & 75.4 & 844.1 & 872.6 & 11488.6 & 13205.3 & 29297.4 \\
\hline & 1.54 & 19916.2 & 2517.2 & 628.1 & 2.45 & 18.1 & & 108.6 & 844.1 & 872.6 & 11488.6 & 13205.3 & 36377.9 \\
\hline & 1.8 & 27108.2 & 3426.2 & 854.9 & 3.34 & 24.64 & & 147.8 & 844.1 & 872.6 & 11488.6 & 13205.3 & 44745.8 \\
\hline \multirow{5}{*}{ SM2 } & 0.77 & 1035.1 & 629.3 & 157 & 0.61 & 4.53 & & 27.2 & 845.7 & 872.6 & 11488.6 & 13206.9 & 15056.1 \\
\hline & 1.03 & 1840.2 & 1118.8 & 279.1 & 1.09 & 8.05 & & 48.3 & 845.7 & 872.6 & 11488.6 & 13206.9 & 16494.4 \\
\hline & 1.29 & 2875.4 & 1748.1 & 436.2 & 1.7 & 12.57 & 6 & 75.4 & 845.7 & 872.6 & 11488.6 & 13206.9 & 18343.7 \\
\hline & 1.54 & 4140.5 & 2517.2 & 628.1 & 2.45 & 18.1 & & 108.6 & 845.7 & 872.6 & 11488.6 & 13206.9 & 20603.8 \\
\hline & 1.8 & 5635.7 & 3426.2 & 854.9 & 3.34 & 24.64 & & 147.8 & 845.7 & 872.6 & 11488.6 & 13206.9 & 23274.9 \\
\hline
\end{tabular}


Table 7. Continue.

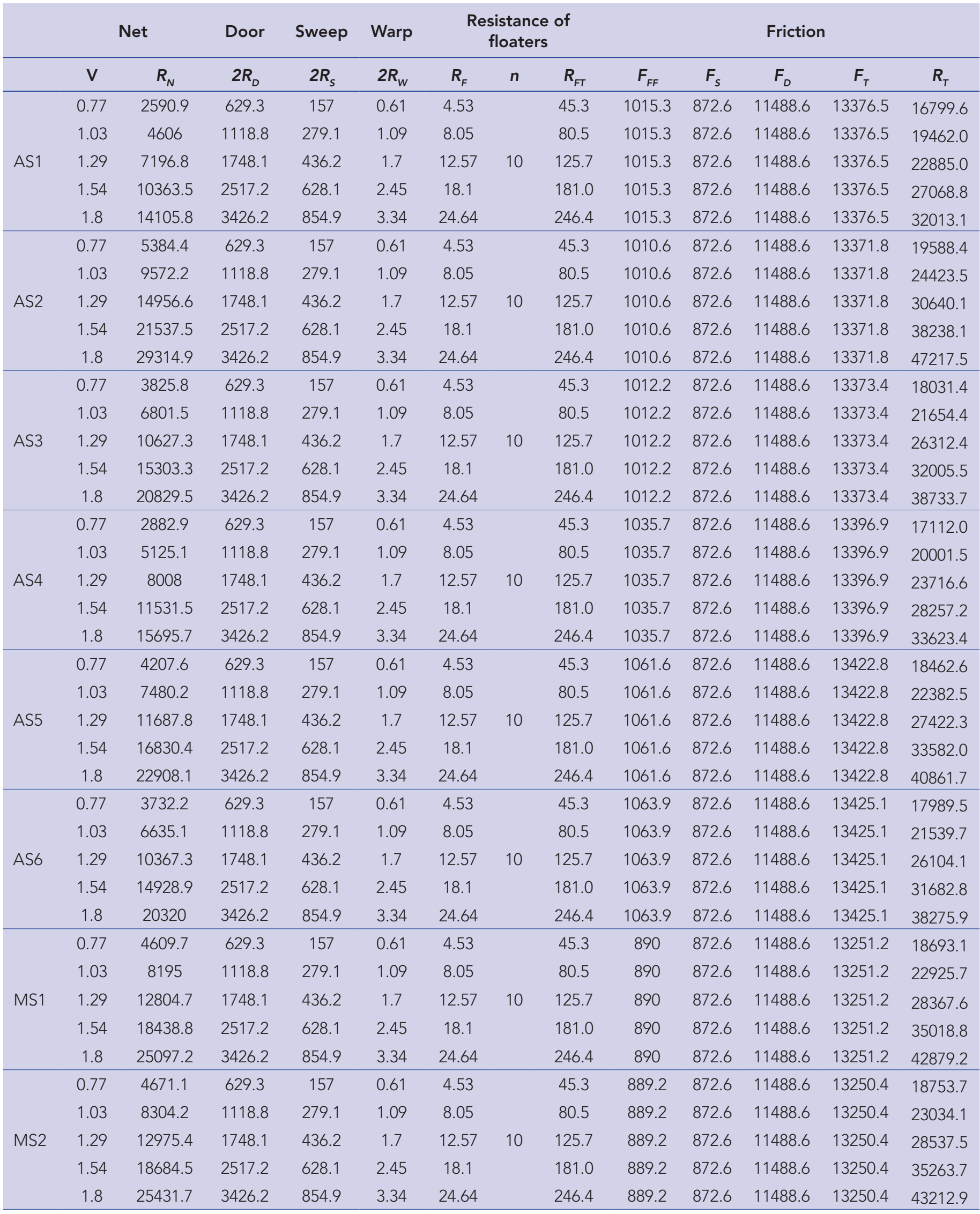


Table 7. Continue.

\begin{tabular}{|c|c|c|c|c|c|c|c|c|c|c|c|c|c|}
\hline & \multicolumn{2}{|c|}{ Net } & \multirow{2}{*}{$\begin{array}{l}\text { Door } \\
2 R_{D}\end{array}$} & \multirow{2}{*}{$\begin{array}{c}\text { Sweep } \\
2 R_{\mathrm{S}}\end{array}$} & \multirow{2}{*}{$\begin{array}{c}\text { Warp } \\
2 R_{w}\end{array}$} & \multicolumn{3}{|c|}{$\begin{array}{l}\text { Resistance of } \\
\text { floaters }\end{array}$} & \multicolumn{5}{|c|}{ Friction } \\
\hline & V & $R_{N}$ & & & & $R_{F}$ & $n$ & $R_{F T}$ & $F_{F F}$ & $F_{s}$ & $F_{D}$ & $F_{T}$ & $R_{T}$ \\
\hline \multirow{5}{*}{ MS3 } & 0.77 & 4553.5 & 629.3 & 157 & 0.61 & 4.53 & & 45.3 & 926.1 & 872.6 & 11488.6 & 13287.3 & 18673.0 \\
\hline & 1.03 & 8095.2 & 1118.8 & 279.1 & 1.09 & 8.05 & & 80.5 & 926.1 & 872.6 & 11488.6 & 13287.3 & 22862.0 \\
\hline & 1.29 & 12648.7 & 1748.1 & 436.2 & 1.7 & 12.57 & 10 & 125.7 & 926.1 & 872.6 & 11488.6 & 13287.3 & 28247.7 \\
\hline & 1.54 & 18214.1 & 2517.2 & 628.1 & 2.45 & 18.1 & & 181.0 & 926.1 & 872.6 & 11488.6 & 13287.3 & 34830.2 \\
\hline & 1.8 & 24791.4 & 3426.2 & 854.9 & 3.34 & 24.64 & & 246.4 & 926.1 & 872.6 & 11488.6 & 13287.3 & 42609.5 \\
\hline \multirow{5}{*}{ MS4 } & 0.77 & 7187.9 & 629.3 & 157 & 0.61 & 4.53 & & 45.3 & 923.8 & 872.6 & 11488.6 & 13285 & 21305.1 \\
\hline & 1.03 & 12778.5 & 1118.8 & 279.1 & 1.09 & 8.05 & & 80.5 & 923.8 & 872.6 & 11488.6 & 13285 & 27543.0 \\
\hline & 1.29 & 19966.4 & 1748.1 & 436.2 & 1.7 & 12.57 & 10 & 125.7 & 923.8 & 872.6 & 11488.6 & 13285 & 35563.1 \\
\hline & 1.54 & 28751.6 & 2517.2 & 628.1 & 2.45 & 18.1 & & 181.0 & 923.8 & 872.6 & 11488.6 & 13285 & 45365.4 \\
\hline & 1.8 & 39134.1 & 3426.2 & 854.9 & 3.34 & 24.64 & & 246.4 & 923.8 & 872.6 & 11488.6 & 13285 & 56949.9 \\
\hline
\end{tabular}

length, the other nets had lower values. The main reasons for this case could be due to the twine diameter (see Table 2) of the net and the additional weight of the footrope which directly affected the footrope friction. On the other hand, the second and third greatest resistance values were determined for AS2, MS2, respectively. MS4, AS2, MS2 were all traditional nets, indicating that traditional type nets composed more resistance than tailored ones in general.

Although the total twine surface area of AS6 is greater than MS1, AS2, MS2, MS3, SM1, MS4 and AS5, only the net resistance of those gears is bigger than that of AS6. This is due to the material of the filament, twine diameter, mesh size and length of the headrope. Düzbastılar et al. (2003), revealed the resistance values of conventional and tailored demersal trawl nets with various trawling speed and operation depth based on theoretical calculations. The authors calculated the total resistance of conventional and tailored trawl gears to be 7.5 and $6.9 \mathrm{kN}$, respectively at $100 \mathrm{~m}$ depth with a towing speed of $1.29 \mathrm{~ms}^{-1}$ ( $2.5 \mathrm{knot}$ ). Considerable differences between the two studies are attributable to the magnitude of the nets, twine diameter and more importantly the impact of friction which was omitted by Düzbastılar et al. (2003).

The reason for low resistance in N8 and high resistance in MS4 is attributable to twine diameter. Almost all sections of the MS4 were rigged by $P E \varnothing 0,253 * 10$ material which resulted in thicker twines. The bigger the twine is, the more the net resists. The use of smaller diameter twines and change in the twine materials of trawl netting are reported to be other methods in order to achieve reduced drag. This situation was confirmed by Verhulst \& Jochems (1993). Researchers, conducting a series of experimental fishing operations by replacing polyamide ropes with ropes made of resistant Dyneema SK 60 in the front part of a large Dutch pelagic trawl, reported that it was possible to achieve $\sim 10 \%$ higher towing speed for the same engine power with the new type of rope. They also noted that the mouth area of the net increased by 25\%, apart from the increased towing speed. Other methods used for achieving reduced drag are the use of smaller diameter twines and change in the twine materials of trawl netting. Verhulst \& Jochems (1993) conducted a series of experimental fishing operations by replacing polyamide ropes with ropes made of resistant Dyneema SK 60 in the front part of a large Dutch pelagic trawl. The results show that it is possible to achieve a 10\% higher towing speed for the same engine power with the new type of rope. It was reported that the door can comprise $30-35 \%$ of the total drag of the trawl gear and thus 30-35\% of the fuel usage (Bankston, 1988). Nearly $50 \%$ of the total resistance (door frictions $41.3 \%$ and resistances of doors $6.3 \%$ ) was obtained by doors and their interactions with the ground in our study. Therefore, doors are one of the most important elements of the trawl fishery in terms of hydrodynamic impacts.

Despite the increasing length over all (LOA) and engine power of trawlers and improved net structures, almost the same door design and structure have been used in the Turkish demersal trawl fishery for many years (Aydın \& Düzbastılar, 2011). In this study, each trawl door resistance varied in a wide range from $314 \mathrm{~N}$ to $1713 \mathrm{~N}$. There are other types of doors creating less resistance values (SEAFISH, IFREMER \& DIFTA 1995). Such types should be theoretically examined and observed during trawl operations in the Turkish demersal trawl fishery to reduce the resistance, thus, the fuel consumption.

It is possible to calculate the resistance values of whole trawl gear in different sizes and properties by theoretical resistance calculations. While most of the previous studies took into account the design of the gear, the water speed, and the bottom contact (Ward \&Ferro, 1993; Ferro et al., 1996; Sala, De Carlo, Buglioni, \& Lucchetti, 2011; Park, 2007; Lee et al., 2005; Tsukrov et al., 2003; Priour, 2013) but there are few studies on catch effect (O’Neill, Knudsen, Wileman, \& McKay, 2005.; Priour \& Herrmann, 2005). Detailed investigation of catch weight influence 


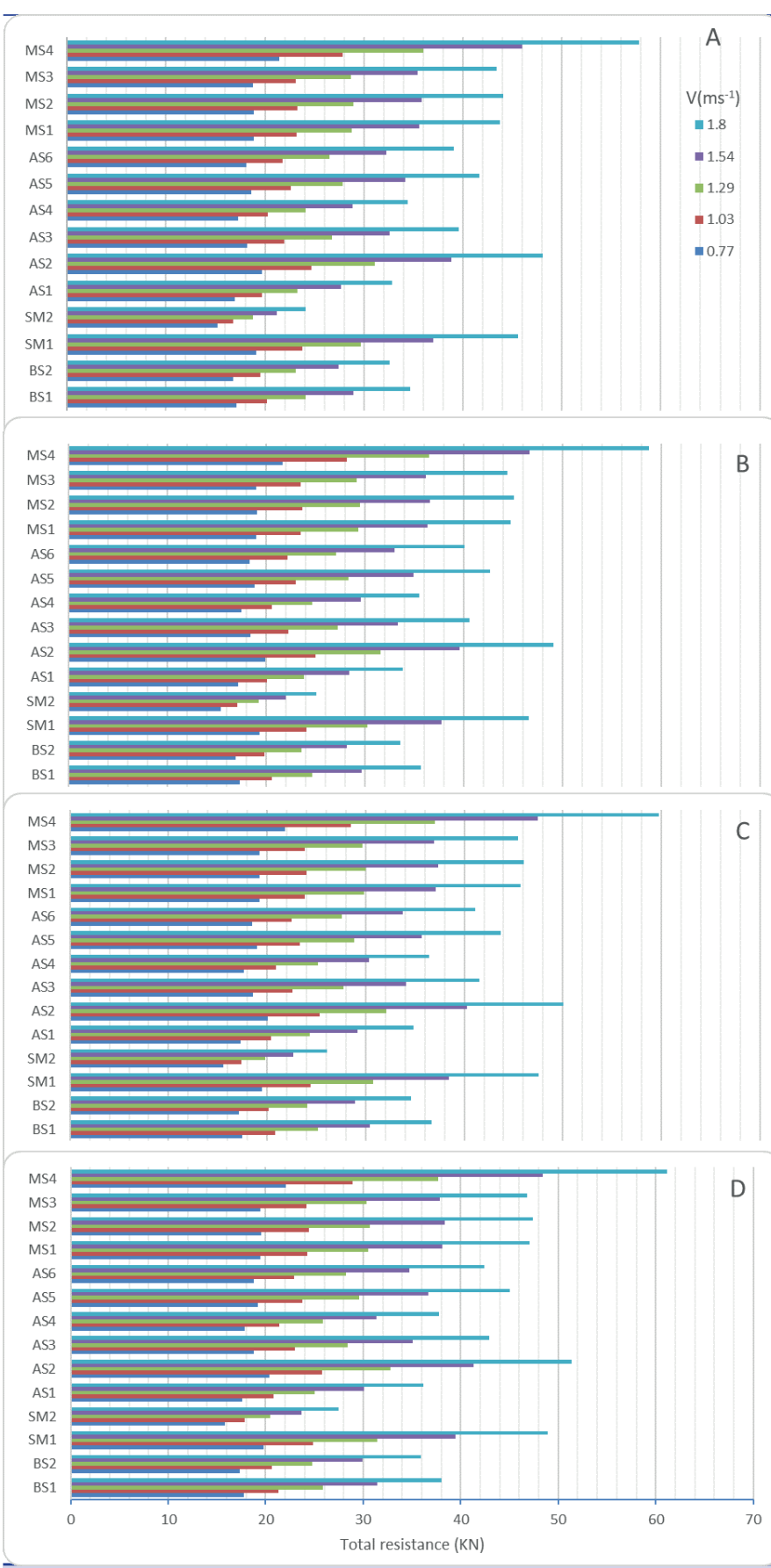

Figure 5. Total resistance values $(\mathrm{kN})$ of the examined trawl gears according to four different warp lengths ((A) $500 \mathrm{~m}$, (B) $1100 \mathrm{~m},(\mathrm{C}) 1700 \mathrm{~m}$, (D) $2500 \mathrm{~m})$.

on trawl behavior based on sea trials was carried out by Daniel \& Amelia (2015) and they stated that besides the catch weight, catch volume is also very important because the density of fish is not exactly the density of water, and this difference could slightly affect the volume of the catch. Therefore, biological factors must be added into the calculations in order to make factual estimations in further studies. It is also very important to measure the tension on the warp with suitable force gauges for accurate determination of the total resistance of the trawl gear. Although Düzbastılar et al. (2003), reported total resistance of traditional and tailored bottom trawl nets, they excluded the effect of bottom contact and floater resistance from their calculations. Moreover, our study, parallel with that of Düzbastılar et al (2003), is missing the influence of catch weight on trawl behavior. At this point, as mentioned by Daniel \&Amelia (2015), taking the catch mass and volume into account becomes very important in order to reflect or at least to reliably simulate the actual response of the gear.

\section{CONCLUSION}

Different types of trawl nets have been operated in the Turkish demersal trawl fishery according to the target species. Hydrodynamic resistance of the most common ones was theoretically estimated in the study. The greatest contributions to total resistance were composed of door friction, net and doors, respectively. Twine thickness and additional weights on the footrope were also determined to be major parameters directly affecting the net resistance. The present work is considered to inspire further studies on mathematical modelling of bottom trawl gears and, thus, comprehensive projects which contribute to the trawling efficiency will be performed.

Conflict of interests: The authors have no conflicts of interest to declare.

Ethics committee approval: This study was conducted in accordance with ethics committee procedures of animal experiments.

\section{Funding: -}

\section{Acknowledgments: -}

\section{Disclosure: -}

\section{REFERENCES}

Amoroso, R. O., Pitcher, C. R., Rijnsdorp, A. D., McConnaughey, R. A., Parma, A. M., Suuronen, P. \& Jennings, S. (2018). Bottom trawl fishing footprints on the world's continental shelves. Proceedings of the National Academy of Sciences of the United States of America, 115, E10275-E10282. [CrossRef]

Aydın, C. \& Düzbastılar, F.O. (2011). Otter boards' performances and design criteria. Ege Journal of Fisheries and Aquatic Sciences, 28(4), 127-136.

Aydın, C., Tokaç, A., Ulaş, A., Maktay, B. \& Şensurat, T. (2011). Selectivity of $40 \mathrm{~mm}$ square and $50 \mathrm{~mm}$ diamond mesh codends for five species in the Eastern Mediterranean demersal trawl fishery. African Journal of Biotechnology, 10(25), 5037-5047.

Aydın, C. \& Tosunoğlu, Z. (2009). Selectivity of square and hexagonal mesh codends for deep water rose shrimp Parapenaeus longirostris (Lucas, 1846) (Decapoda, Penaeidae) in the Aegean Sea. Crustaceana, 82, 89-98. [CrossRef]

Balash, C. (2012). University of Tasmania (2017, October 11). Retrived October 01, 2021, from https://eprints.utas.edu.au/14737/1/frontbalash-thesis.pdf

Bankston, J.D. (1988). Otter Doors and fuel consumption. Lousiana Cooperative Extension Service, DB78002.

Bilecenoğlu, M., Kaya, M., Cihangir, B. \& Çiçek, E. (2014). An updated checklist of the marine fishes of Turkey. Turkish Journal of Zoology, 38, 901-929. [CrossRef] 
Cashion, T., Al-Abdulrazzakb, D., Belhabibc, D., Derricka, B., Divovicha, E., Moutopoulosd, D. K., Noëla, S., Palomaresa, M.L.D., Tehe, L.C.L., Zellerg, D. \& Pauly, D. (2018). Reconstructing global marine fishing gear use: catches and landed values by gear type and sector. Fisheries Research, 206, 57-64. [CrossRef]

Daniel, P. \& Amelie, D. P. (2015). An experimental/numerical study of the catch weight influence on trawl behavior. Ocean Engineering, 94, 94102. [CrossRef]

Demirci, A., Tosunoğlu, Z. \& Demirci, S. (2008). A study on shrimp trawl designs and modifications in iskenderun bay (Turkey). Journal of FisheriesSciences.com, 2(5), 666-671. [CrossRef]

Düzbastılar, F. O., Tosunoğlu, Z. \& Kaykaç, M. H. (2003). Geleneksel ve Kesimli Dip Trol Ağları ile Donam Dirençlerinin Teorik Olarak Hesaplanması. Ege Journal of Fisheries and Aquatic Sciences,, 20(12), 15-25.

Düzbastılar, F. O., Aydın, C., Metin, G., Lök, A., Ulaş, A., Özgül, A. \& Tokaç, A. (2010). Survival of fish after escape from a $40 \mathrm{~mm}$ stretched diamond mesh trawl codend in the Aegean Sea. Scientia Marina, 74(4), 755-761. [CrossRef]

Fiorentini, L., Sala, A., Hansen, K., Cosimi, G. \& Palumbo, V. (2004). Comparison between model testing and full-scale trials of new trawl design for Italian bottom fisheries. Fisheries Science, 70, 349-359. [CrossRef]

Fridman, A. L. (1969). Theory and design of commercial fishing gear. Moscow: Pischevaya Promyshlennost.

Fridman A. L. (1973). Theory and design of commercial fishing gear, Chapter XX1, Translated from Russian, Israel Program for Scientific Translations, Jerusalem

Ferro, R.S.T., van Marlen, B. \& Hansen K.E. (1996). An empirical velocity scale relation for modelling a design of large mesh pelagic trawl. Fisheries Research, 28(2), 197-230. [CrossRef]

Kaykaç, M. H., Düzbastılar, F. O., Zengin, M., Süer, S. \& Rüzgar, M. (2017). Measurements of fuel consumption and towing resistance in Sea Snail beam trawl fisheries: Preliminary results. Turkish Journal of Fisheries and Aquatic Sciences, 17(5), 901-909. [CrossRef]

Kaykaç, M. H., Zengin, M., Özcan-Akpınar, I. \& Tosunoğlu, Z. (2014). Structural characteristics of towed fishing gears used in the Samsun coast (Black Sea). Ege Journal of Fisheries and Aquatic Sciences, 31(2), 87-96. [CrossRef]

Lee, C.-W., Lee J.-H., Cha B.-J., Kim H.-Y. \& Lee, J.-H. (2005). Physical modeling for underwater flexible systems dynamic simulation. Ocean Engineering, 32(3-4), 331-347. [CrossRef]

Nomura, M. \& Yamazaki, T. (1975). Fishing techniques; compilation of transcript of lectures presented at the Training Department, SEAFDEC (Southeast Asian Fisheries Development Center).

O’Neill, F.G., Knudsen, L.H., Wileman, D.A. \& McKay, S.J. (2005). Codend drag as a function of catch size and towing speed. Fisheries Research, 72, 163-171. [CrossRef]

Özbilgin, H., Gökçe, G., Özbilgin, Y., Yalçın, E., Alp, M.T.,\& Sağlamtimur, B. (2018). To determine the fish behavior in demersal trawl mouth and to increase species selectivity by modification of ground gear (Report No. 1150647). TUBITAK.

Özbilgin, H., Tokaç, A., \& Kaykaç, H. (2012). Selectivity of commercial compared to larger mesh and square mesh trawl codends for four fish species in the Aegean Sea. Journal of Applied Ichthyology, 28(1), 51-59. [CrossRef]

Özdemir, S., Erdem, Y., Erdem,E., \& Birinci, Z.Ö. (2014). Effects of square mesh panels position of bottom trawls on by-catch bluefish Pomatomus saltatrix (Linnaeus, 1776) selectivity in the Southern Coast of the Black Sea, Turkey. Cahiers de Biologie Marine, 55, 315321.
Park, H.H. (2007). A method for estimating the gear shape of a mid-water trawl. Ocean Engineering, 34, 470-478. [CrossRef]

Pereira, J. F. (2012). Dynamic modeling of trawl fishing gear components. Ciencia y tecnología de buques, 6(11), 57-65. [CrossRef]

Priour, D. (2013). A Finite element method for netting: Application to fish cages and fishing gear. Springer Science \& Business Media. ISBN 978-94-007-6843-7.

Priour, D. \& Herrmann, B. (2005). Catch shape in cod-end. In Proceedings of the 7th International Workshop on Methods for the development and evaluation of maritime technologies, Busan, South Korea (pp. 23-26).

Priour, D. (2009). Numerical optimization of trawls design to improve their energy efficiency. Fisheries Research, 98(1-3), 40-50. [CrossRef]

Sala. (2013). Final project report Technical specifications of Mediterranean trawl gears (myGears). (Report No. 5). EC Commission

Sala, A., De Carlo, F., Buglioni, G. \& Lucchetti, A. (2011). Energy performance evaluation of fishing vessels by fuel mass flow measuring system. Ocean Engineering, 38 (5-6), 804-809. [CrossRef]

SEAFISH, IFRAMER, \& DIFTA. (1995). Otter board performance and behavior. Commission of the European Communities. (Report No. TE 1214). EEC research program in the fisheries sector (FAR).

Soykan, O., Akgül, Ş. A. \& Kınacıgil, H. T. (2016). Catch composition and some other aspects of bottom trawl fishery in Sığacık Bay, central Aegean Sea, eastern Mediterranean. Journal of Applied Ichthyology, 32(3), 542-547. [CrossRef]

Soykan, O., Bakır, K. \& Kınacıgil, H. T. (2019). Demersal trawl discards with spatial and bathymetric emphasis in the Turkish coast of the Aegean Sea. Marine Biology Research, 15(1), 113-123. [CrossRef]

Stewart, P. (2002). A Review of Studies of Fishing Gear Selectivity in the Mediterranean. (Report No. 9). FAO COPEMED.

Tang, M.F., Dong, G.H., Xu, T.J., Zhao, Y.P. \& Bi, C.W. (2017). Numerical simulation of the drag force on the trawl net. Turkish Journal of Fisheries and Aquatic Sciences, 17 (6), 1219-1230. [CrossRef]

Tokaç, A., Herrmann, B., Aydın, C., Kaykac, H., Ünlüler, A. \& Gökce, G. (2014). Predictive models and comparison of the selectivity of standard (T0) and turned mesh (T90) codends for three species in the Eastern Mediterranean. Fisheries Research, 150, 76-88. [CrossRef]

Tokaç, A., Ünal, V., Tosunoğlu, Z., Akyol, O., Özbilgin, H. \& Gökçe, G. (2010). Ege Denizi Balıkçılığı. IMEAK Deniz Ticaret Odası İzmir Şubesi Yayınları.

Tosunoğlu, Z. \& Aydın, C. (2007). Technical characteristics of demersal trawl nets recently used in the Turkish coast of the Aegean Sea. Journal of FisheriesSciences.com, 1(4), 184-187. [CrossRef]

Tsukrov, I., Eroshkin, O. Fredriksson, D. Swift M.R. \& Çelikkol B. (2003). Finite element modeling of net panels using a consistent net element. Ocean Engineering, 30(2), 251-270. [CrossRef]

Verhulst, N., \& Jochems, J. (1993). Final Confidential Report for the Project TE 1.102 HP NET'92 Research Project Financed by the Commission of the European Communities Within the Frame of the EEC Research Programme in the Fisheries Sector ("FAR").

Ward, J.N. \& Ferro, R.S.T. (1993). A comparison of one-tenth and fullscale measurements of the drag and geometry of a pelagic trawl. Fisheries Research, 17(3-4), 311-331. [CrossRef]

Winger, P. D., DeLouche, H. \& Legge, G. (2006). Designing and testing new fishing gears: the value of a flume tank. Marine Technology Society Journal, 40(3), 44-49. [CrossRef]

Zengin, M., Polat, H., Kutlu, S., Dinçer, A.C., Güngör, H., Aksoy, M., Özgündüz, C., Karaslan, E. \& Fifan, Ş. (2004). Studies on the Fishery Development of the Deep water pink shrimp (Parapenaeus longirostris, Lucas 1846) in the Marmara Sea. (Report No. TAGEM/ HAYSUD/2001/09/02/004). T.C. Tarım ve Köyişleri Bakanlığı Tarımsal Araştırmalar Genel Müdürlüğü. 